However, it is not clear how this might apply in the context of those dying in critical care. We conducted a national survey targeting critical care staff to investigate experiences and attitudes towards transferring critical care patients home to die (HtD).

Aims and Methods An online survey was developed informed by the literature and analysis of six focus groups with Health Care Professionals (HCPs) to assess (1) experience and (2) views. The lead consultant and lead nurse of 409 critical care units in the UK were invited, by e-mail, to take part.

Results A total of $180 \mathrm{HCPs}$ completed the online survey (response rate 24\%). Experience with transferring $\mathrm{HtD}$ was reported by $36 \%$. The majority agreed that transferring patients $\mathrm{HtD}$ is a good idea in principle $(89 \%)$ and that transfer is important in terms of preferred place of death (PPD) (82\%). 36\% agreed that it would be unethical to prolong a patient's life to facilitate a transfer and 13\% agreed that a transfer was not worth the risk of dying in the ambulance. Statistically significant differences for some views were found for physicians and nurses, and for those with and without experience of transferring HtD.

Conclusions This study is the first to explore views of health care professionals about transferring patients from critical care HtD. Respondents' views were generally positive, particularly about honouring PPD but reservations were expressed in terms of ethical concerns and the risk of dying on route.

OP 04 A NATIONAL SURVEY EXPLORING VIEWS AND EXPERIENCE OF HEALTH PROFESSIONALS ABOUT TRANSFERRING PATIENTS FROM CRITICAL CARE HOME TO DIE

A S E Darlington, * T Long-Sutehall, J Addington-Hall, A Richardson, M A Coombs Faculty of Health Sciences, University of Southampton, Southampton, UK

10.1136/bmjspcare-2013-000453a.4

Introduction Progress has been made towards enabling patients to die in their preferred place of care. 
BMJ

Supportive

\& Palliative

Care

\section{A NATIONAL SURVEY EXPLORING VIEWS AND EXPERIENCE OF HEALTH PROFESSIONALS ABOUT TRANSFERRING PATIENTS FROM CRITICAL CARE HOME TO DIE}

A S E Darlington, T Long-Sutehall, J Addington-Hall, et al.

BMJ Support Palliat Care 2013 3: 125

doi: 10.1136/bmjspcare-2013-000453a.4

Updated information and services can be found at:

http://spcare.bmj.com/content/3/1/125.2

These include:

Email alerting Receive free email alerts when new articles cite this article. Sign up in service the box at the top right corner of the online article.

Notes

To request permissions go to:

http://group.bmj.com/group/rights-licensing/permissions

To order reprints go to:

http://journals.bmj.com/cgi/reprintform

To subscribe to BMJ go to:

http://group.bmj.com/subscribe/ 